\title{
The Attitude and Readiness Towards Interprofessional Education (IPE) Among Medical Teachers of Universitas Muhammadiyah Jakarta
}

\author{
Savira Dwi Ramadini ${ }^{1}$, Oktarina ${ }^{2}$ \\ 1) Medical Study Program, Faculty of Medicine and Health, Universitas Muhammadiyah Jakarta, Indonesia \\ 2) Medical Education Department, Faculty of Medicine and Health, Universitas Muhammadiyah Jakarta, Indonesia \\ *Corresponding author: oktarina@umj.ac.id
}

\begin{abstract}
Background: Geriatric has multi-problems which need inter-disciplinary supports including collaboration among health professionals. To realize the importance of collaboration among health workers is to encourage collaboration since educational process. Teachers play an important role in conducting an Interprofessional Education (IPE). Purposes: To describe the attitudes and readiness of medical teachers of Universitas Muhammadiyah Jakarta (UMJ) towards IPE in 2019. Methods: The subjects of the study were medical teachers of UMJ with a sample size of 34 respondents. It was conducted at UMJ on November-December 2019. The instrument used for measuring the variable of attitude is the Attitudes toward Health Care Teams Scale (ATHCTS), whilst Readiness for Interprofessional Learning Scale (RIPLS) questionnaire was for the readiness. Results: It was found respondents who had attitudes in the good and fairly good categories were $62 \%$ and $38 \%$ respectively. Based on their state of readiness, $85 \%$ of the respondents were adequate, $15 \%$ moderate, and none not ready. Conclusion: Most of the respondents had a good attitude and ready for IPE. It was found that the aspects of the role in the team are mostly fairly good compared to aspects of values in the team and efficiency in the team which are mostly in the good category. The readiness showed adequate state in 2 aspects which are teamwork and collaboration and professional identity, whilst the aspect of role and responsibility was moderate. Consequently, improvement should be directed for the attitude to play a role in the team and the readiness in role and responsibility aspects.
\end{abstract}

Keywords: attitude, interprofessional education, medical teacher, readiness

\section{INTRODUCTION}

Geriatric is a physiological phase that has multi problems. Those needs need inter-disciplinary supports including collaboration among health professionals. According to Keith (2008), the key for quality health services at an efficient cost is to increase effective collaboration between health workers (1). Effective interdisciplinary teams is essential for successful comprehensive geriatric assessment.
Collaborating in high performing teams should be prioritized in healthcare for older people. Conducting training in the same context among health workers can improve team performance. Later on, the outcomes for patients will be increased as well. The training in should strengthen non-technical skills i.e. leadership, communication, team-working, etc. Those skills are should be evaluated periodically 
throughout clinical practice in order to obtain an optimal performance.

One of the efforts to train the collaboration between health workers is to introduce collaborative practices earlier since educational process $(2,3)$. Interprofessional education (IPE) is an integrated education concept for increasing collaboration skills (1). IPE is also a strategy and an early stage to increase teamwork that can encourage collaborative practices.

Data from the World Health Organization (2010) shows the percentage of professions involved in implementing IPE in educational institutions in several countries, including 16\% nurses, $10.2 \%$ doctors and nutritionists with a value of $5.7 \%$. This indicates that IPE has begun to receive attention in health professional education (4). In Indonesia, collaboration between health professions is still far from ideal because there are still overlapping roles between professions. This is due to the lack of understanding of a health profession on the competencies of other health professions.

The development of the IPE curriculum is important to promote service quality both in the clinical phase and educational phase. Institutions play an important role in creating a supportive atmosphere for the development of IPE, including teachers who can become role models in learning. Teacher preparation is one of the important points to support the success of the IPE learning model. The preparation required is the knowledge and experience of the teacher regarding IPE itself (5). There was no evidence about the aspects that needs to be improved among teachers to facilitate IPE in Universitas Muhammadiyah Jakarta. Therefore, a study to describe the attitudes and readiness among medical teachers Universitas Muhammadiyah Jakarta was needed.

\section{METHODS}

This study used a descriptive design to describe the attitude and readiness of IPE of medical teachers of Universitas Muhammadiyah Jakarta. This research was conducted at the Faculty of Medicine and Health, Universitas Muhammadiyah Jakarta during October - November 2019. The subjects of this study were medical teachers. The samples was selected by a purposive sampling method on active teachers, registered in the Higher Education Database (PDDIKTI), and willing to participate in this research. The minimum sample size needed is 31 people based on the Slovin formula from the population of 45 .

The variables examined in this study were attitudes and readiness for IPE. The IPE Attitudes variable (IA) was measured using the Attitudes Toward Health Care Teams Scale (ATHCTS) questionnaire which contained 21 questions. This questionnaire explores attitudes with the value component in the team, the efficiency of a team, and the role in a team using a 4point Likert scale (Strongly disagree to strongly agree). This variable measuring scale is ordinal with good, adequate, and insufficient categories. Good category if the score IA $\geq 76$, fairly good if the score is 56 $<$ IA $<75$, while it is declared insufficient if the score is IS $\leq 55$.

Meanwhile, the IPE Readiness (IR) variable was measured using the Readiness Questionnaire for Interprofessional Learning Scale (RIPLS). This questionnaire measures Teamwork and collaboration, Professional Identity, and Roles and Responsibilities consisting of 19 questions on a 5-point Likert scale (strongly agree to strongly disagree). The score data obtained were categorized into ordinal data with the 
following groupings IR> 75 Adequate, 54 $<$ IR < 75 Moderate, and IR <54 Poor (6).

Primary data was collected by distributing questionnaires to respondents. Researchers assisted respondents when filling out the questionnaire to avoid unwanted mistakes and to help respondents to understand so that respondents could answer the questionnaire properly and clearly. Therefore, the data was analysed descriptively.

Ethical approval number 146/PE/KE/ FKK-UMJ/X/2019 for this study was obtained from Medical Research Ethics Committee, Faculty of Medicine and Health, Universitas Muhammadiyah Jakarta.

\section{RESULT}

The number of samples obtained in the study was 34 people with a distribution of respondent characteristics based on gender, age, and education level. Respondents were male $26.5 \%$ and female $73.5 \%$. Most of the respondents were 38-46 years old (41\%), while the smallest proportion $6 \%$ was above 50 years old. More than $90 \%$ of the respondents have a Master degree or Specialization (Sp-1) background, while the number of respondents with a Doctoral degree/Sub-specialization education is only 1 person.

Table 1. Respondents by age

\begin{tabular}{lcc}
\hline \multicolumn{1}{c}{ Age } & $\begin{array}{c}\text { Amount } \\
(\mathbf{n})\end{array}$ & $\begin{array}{c}\text { Percentage } \\
(\boldsymbol{\%})\end{array}$ \\
\hline$<34$ years & 5 & 15 \\
34 - 38 years & 6 & 18 \\
38 - 46 years & 14 & 41 \\
46 - 50 years & 7 & 20 \\
$>$ 50 years & 2 & 6 \\
\hline Total & 34 & 100 \\
\hline
\end{tabular}

\section{Attitude of teachers towards IPE}

The ATHCTS questionnaire has a correlation value $0.439-0.895$ with a Cronbach alpha 0.979 in the previous studies. In Aryakhiyati's (2011) study, the results of the validity test of the RIPLS questionnaire were that $\mathrm{r}$ count was in the range $0.470-0.905$ with $r$ table 0.444 . The reliability of this questionnaire was indicated by the results of Cronbach alpha 0.914 .

Respondents with attitudes towards IPE in good categories were 21 respondents $(61.8 \%)$, with fairly good category as many as 13 respondents (38.2\%), and with insufficient category as many as 0 respondents.

\section{ATTITUDE OF TEACHERS TOWARDS}

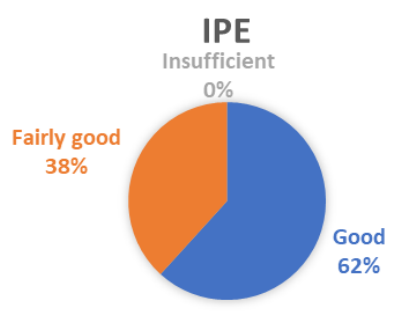

Figure 1. Attitude of teachers towards IPE

Attitudes towards IPE in the aspect of value in the team were distributed in good categories as many as 24 (70.6\%) respondents, with $10(29.4 \%)$ respondents in fairly good category, and 0 respondents in the insufficient category.

The aspect of efficiency in the team as a form of attitude towards IPE with a good category was owned by 21 respondents $(61.8 \%)$, with 12 respondents $(35.3 \%)$ in the fairly good category, and 1 respondent $(2.9 \%)$ in the insufficient category.

The third aspect in attitudes towards IPE, the role in the team, has the following proportions: good category as many as 10 
(29.4\%) respondents; Fairly good category as many as $23(67.6 \%)$ respondents; and the insufficient category was 1 respondent $(2.9 \%)$.

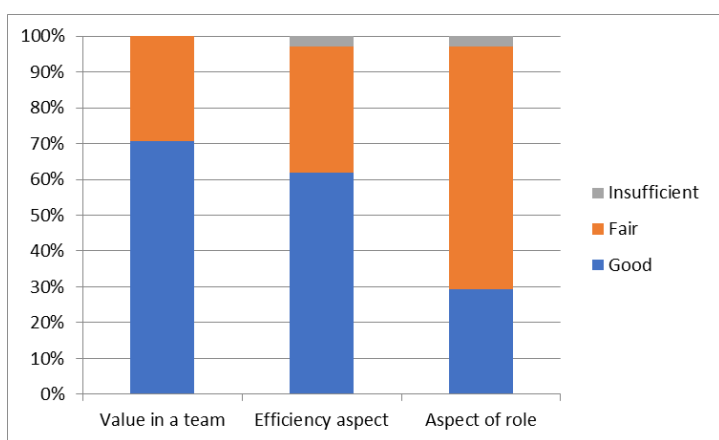

Figure 2. Attitudes Toward Health Care Teams based on 3 aspects

\section{Readiness of Medical Teachers of UMJ}

Most of the respondents have an adequate category of IPE Readiness, as many as 29 respondents (85.3\%). Meanwhile, in the moderate category, there were 5 respondents $(14.7 \%)$ and 0 respondents in the poor category.

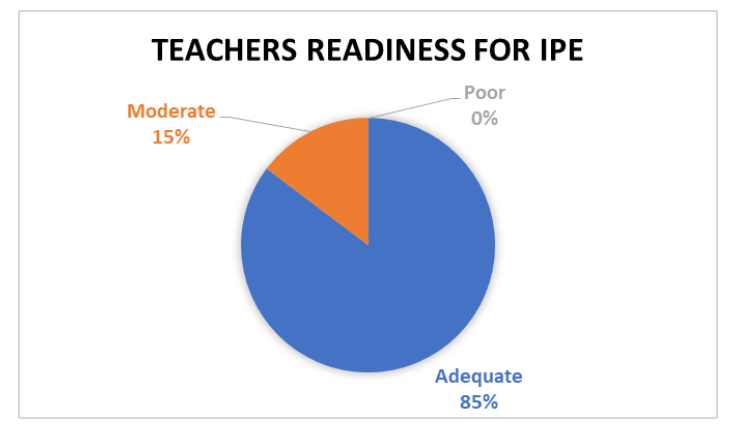

Figure 3. Teacher readiness for IPE

When viewed from each aspect of readiness, it was found that $30(88.2 \%)$ respondents had readiness for IPE in the aspects of teamwork and collaboration in the adequate category, $3(8.8 \%)$ respondents were in the moderate category, and there were no respondents with poor category.

Readiness for IPE in the aspect of professional identity, there were $28(82.4 \%)$ respondents in the adequate category, 6
$(17.6 \%)$ respondents in the moderate category, and no respondents in the poor category.

The third aspect of IPE Readiness is roles and responsibilities. In this aspect, 7 (20.6\%) respondents had adequate readiness, $23(67.6 \%)$ respondents were moderrate, and $4(11.8 \%)$ respondents were poor prepared.

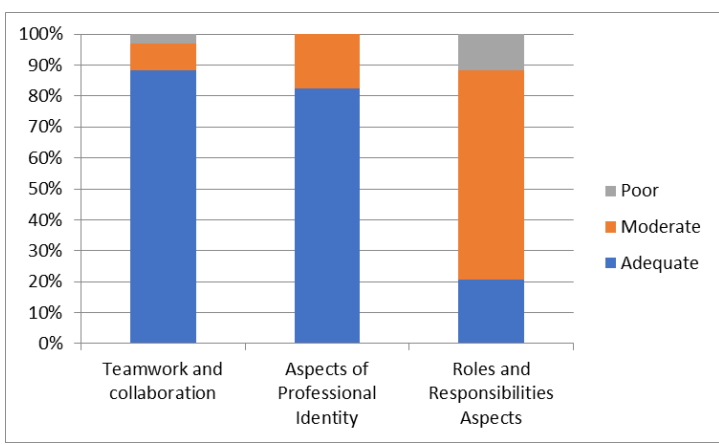

Figure 4. Teacher Readiness for IPE based on 3 aspects

\section{DISCUSSION}

\section{Interprofessional Education (IPE)}

Interprofessional Education (IPE) is a process of groups of 2 or more health professional students to learn within a certain period and collaborate in promotive, preventive, curative, rehabilitative, and other types of health services (7). The characteristic of interprofessional education (IPE) according to Freeth \& Reeves is the change in mindset, knowledge, and behavior of students i.e. a. Students understand the basic principles, concepts, and contributions of each professional field; b. Familiar with terms and mindsets of various types of professions; c. Students must have mastered the basic knowledge and specific skills of each profession; d. Students must master the concept of collaboration (8).

IPE requires active involvement by two or more members of the health care team who participate in both patient assessment and management. The learning process occurs by, with, and from learners 
across disciplines by sharing values and knowledge(8).

Based on the definition of IPE in general, the purpose of IPE itself is for students to learn how to play an appropriate role in teams. The knowledge, values, and skills gained bring into their future practice which can ultimately provide health services collaboratively to improve the outcome for the patient (9). According to Cooper (2001) the objectives of implementing IPE include: 1) Increasing interdisciplinary understanding and cooperation; 2) Build competent cooperation; 3) Make effective and efficient use of resources; 4) Improve the quality of comprehensive patient care (10).

According to Oandasan and Reeves (11), there are direct and indirect factors must be considered in implementing IPE. Factors that directly influence IPE are the theoretical approach used to determine the role of the faculty (facilitator/teacher), student goals, learning strategies, and learning settings. In addition, indirect factors emphasize micro (individual), meso (institutional/organizational level), and macro (political and institutional support).

Eight competencies of IPE teachers or facilitators by Freeth, et al. i.e (1) Has A commitment to interprofessional learning and practice; (2) Trust in relationships is at the specific focus of interprofessional learning to which teaching staff contribute; (3) Become A positive role model; (4) Implement IPE with deep understanding of interactive and confident learning methods; (5) Trust and flexibility to organize different professions competencies within the group; (6) Appreciate the differences and unique contributions of each group member; (7) Match individual needs with group needs; (8) Reassuring and have a sense of humor in the face of adversity.
The IPE learning method can be done through classroom-based learning at the initial stage, namely at the pre-clinical/ academic level, while hospital and community-based learning are beneficial for interprofessional education at the clinical stage.

The benefits of Interprofessional Education include improving practices that can influence service improvement and create positive results in serving clients; increase understanding of the knowledge and skills gained from collaborative work; make students better against the experience gained; can be flexibly applied in various settings (12). World Health Organization (2010) presents the results of research in 42 countries on the impact of implementing collaborative practices. The results of the research turned out to be very promising not only for the countries concerned but also when used in other countries. The study demonstrated the results that collaborative practice can improve 1) affordability and coordination of health services; 2) appropriate use of specific clinical resources; 3) health outcomes for chronic disease; and 4) patient care and safety. Besides, a collaborative practice can reduce 1) total complications experienced by patients; 2) length of hospitalization; 3) tension and conflicts among caregivers; 4) hospital costs; 5) average clinical error; and 6) the average number of patient deaths (13). The benefits of implementing IPE and collaborations can change the way healthcare workers interact with other professions in providing patient care (3).

Barriers that may arise in implementing IPE include the academic calendar, academic regulations, academic reward structures, clinical practice grounds, communication problems, disciplinary departments, professional departments, evaluation, teacher development, 
financial resources, geographical distance, shortage of interdisciplinary teachers, leadership, and administrative support, learner preparation levels, logistics, organizational strength, promotion, attention and reward, change resistance, scholarship, payroll systems, and time commitment (14). According to ASSAF 2018, things that hinder the implementation of IPE are also caused by limited knowledge/understanding of other professions and about IPE, poor perceptions of IPE values and negative attitudes, protection of professional areas, differences in learning styles, and lack of student involvement, as well as high teaching and administrative duties.

Also, Sedyowinarso (2011) said the obstacles that occurred in the implementation of IPE were the ego of each profession, the variety of curricula in each health professional education institution, unclear physical facilities, and learning concepts, paradigms of the health profession, blurred identity and roles of each. In each profession, there is no clarity regarding the legal framework for each health profession and culture (15).

\section{Attitude Towards IPE}

Teaching IPE program is behaviour to response against a stimulus or an observable action in a specific task and has a specific purpose to make students be able to collaborate. Behaviour is greatly influenced by nature or character, attitudes and perceptions owned by someone. Nature or good attitude and perception is needed by medical teachers in IPE program (16).

Overall, the teachers' attitude towards IPE tends to be in a good category. This needs to be taken into account in teacher preparation as an important part of supporting the success of IPE. The preparation required is the knowledge and experience of the teacher regarding IPE itself. If this is not properly prepared, it can lead to a bad perception of the value of IPE which in turn results in a negative attitude. To improve attitudes towards teachers, it can be done by understanding and applying the competence of the facilitator/teacher to IPE itself (16).

The aspect of value in the team and efficiency in the team are two things that were quite strong. This shows an attitude towards values/ethics in acting and cooperating with other professions that are good. Teachers who are in a poor category in this aspect can be caused by limited knowledge/understanding of other professions. To improve this aspect, it is necessary to make efforts to get used to how to work with individuals from other professions to create mutual respect and share common values (17). Teachers' weaknesses in the aspect of efficiency in the team can be caused by less exposure with other professions in particular tasks and a lack of interaction time. In the practice of interprofessional collaboration, this can harm client satisfaction. Efforts to enhance efficiency in the team are by increasing interactions in the form of discussions or other methods that make teachers more efficient in collaborating and giving trust that the team can work effectively when each member is assigned a specific task (18).

From the three aspects of attitudes towards IPE, the role of professions appears to be an aspect with the lowest proportion of "good" category and was dominated by the fairly good category. The low aspect of the role in the team can be caused by a lack of understanding of each other's roles and a lack of involvement in the team itself. The role in the team could be improved by increasing the frequency of collaborating and exchanging roles so that leadership 
knowledge and skills can be trained while managing the team (17).

\section{IPE Readiness}

According to Parsell and Bligh (2009), readiness is the overall nature or strength that makes a person act in a certain way (1). According to Barr, teachers with the readiness to facilitate a good IPE will be better able to help students achieve the expected IPE competencies. Teachers must have a commitment to inter-professional learning and practice.

In implementing IPE, the readiness of teachers is very much needed and can influence the implementation of the IPE. IPE readiness can be seen in three general domains, namely: 1) professional identity, 2) teamwork, 3) roles and responsibilities. These three domains are interconnected in building readiness for IPE implementation $(11,18)$.

In general, IPE readiness showed into an adequate category. The teamwork and collaboration components have the highest value, followed by the professional identity component, and finally the roles and responsibilities component. According to Barr, teachers with the readiness to facilitate a good IPE will be better able to help students achieve the expected IPE competencies. Teachers must have a commitment to inter-professional learning and practice.

Teamwork and collaboration and professional identity are aspects that are quite strong among the medical teachers of FKK UMJ. Only less than 10\% need strengthening in this aspect. Efforts that can be made are to apply the value of relationship building and the principles of team dynamics to perform effectively in different team roles (17).
Aspects that require attention are roles and responsibilities. The adequate category in this aspect is the lowest and dominated by moderate category. This aspect is in line with the aspect of the role in the team in the teachers' attitude towards IPE. An understanding of the roles and responsibilities of each profession allows health professionals to understand the duties of each profession in their work (19). Strengthen readiness in this aspect can be done by increasing knowledge about the roles and responsibilities of each profession.

This study has several limitations where the data were obtained from the results of respondents' answers to the questionnaire and did not make direct observations in the implementation of the IPE.

\section{CONCLUSION}

Most of the medical teachers of FKK UMJ had a good attitude and ready for IPE. However, it was found that the aspects of the role in the team are mostly in the fairly good category compared to aspects of values in the team and efficiency in the team which are mostly in the good category. Based on their state of readiness, most of the respondents were adequate. The readiness showed adequate state in 2 aspects which are teamwork and collaboration and professional identity, whilst the aspect of role and responsibility was in the moderate category. As a consequence, improvement should be directed for the attitude to play a role in the team and the readiness in role and responsibility aspects. 


\section{ACKNOWLEDGMENT}

The authors wish to thank all the teachers participated for their input and the time they invested.

\section{CONFLICT OF INTEREST}

The authors report no conflicts of interest in this work.

\section{REFERENCES}

1. Yuniawan AE, Mulyono WA, Setiowati D. Persepsi dan Kesiapan Dosen Terhadap Pembelajaran Interprofesional. J Keperawatan Soedirman (The Soedirman J Nursing). 2015;2(1):17-23.

2. Bridges D, Davidson RA, Soule Odegard P, Maki I V., Tomkowiak J. Interprofessional collaboration: three best practice models of interprofessional education. Med Educ Online. 2011 Jan 8;16(1):6035.

3. Gilbert JHV, Yan J, Hoffman SJ. A WHO report: Framework for action on interprofessional education and collaborative practice. J Allied Health. 2010;39(SUPPL. 1):196-7.

4. Sulastien H, Syahrul S, Kadar KS. Pengembangan Attitudes Toward Health Care Teams Scale pada Kuliah Kerja Nyata Profesi Kesehatan. J Ilm Kesehat Keperawatan. 2018 Jun $1 ; 14(2)$.

5. Situmorang T. Faktor-faktor Yang Berhubungan Dengan Persepsi dan Kesiapan Dosen Fakultas Kedokteran Universitas Diponegoro Terhadap Interprofessional Education (IPE). Universitas Diponegoro; 2018.

6. Patricia J, Bakri S, Adespin DA. Gambaran Persepsi Dan Kesiapan Dosen Fakultas Kedokteran Universitas Diponegoro Terhadap
Interprofessional Education (IPE). J Kedokt Diponegoro. 2019;8(2):73546.

7. Susanti D, Wulandari H, Juaeriah R, Dewi SP. Penerapan Interprofessional Education (IPE) pada Kelas Ibu Balita oleh Mahasiswa Tenaga Kesehatan untuk Meningkatkan Sikap Ibu terhadap Kesehatan Balita di Kota Cimahi. J Sist Kesehat. 2017 Dec 22;3(2):517.

8. Maria O, Lois $\mathrm{R}$, Smego $\mathrm{R}$. Interprofessional education: a concept analysis. Adv Med Educ Pract. 2010 Nov;1:75-84.

9. Greiner AC, Knebel E. Health Profession Education: A Bridge to Quality Washington (DC). Washington DC: National Academies Press (US); 2003.

10. Sedyowinarso $M$, Claramita $M$. Interprofessional Education (IPE), Communication and Interprofessional Teamwork. In: Prabandar i Y, Tetradewi FF, editors. Buku Acuan Umum CFHCIPE. Yogyakarta: Universitas Gadjah Mada; 2014. p. 98-115.

11. Oandasan I, Reeves S. Key elements of interprofessional education. Part 2: Factors, processes and outcomes. J Interprof Care. 2005 May 6;19(sup1):39-48.

12. Canadian Interprofessional Health Collaborative (CIHC). Canadian Interprofessional Health Collaborative: Activities, outputs and impacts evaluation. Vancouver; 2009.

13. HPEQ-Project. Mahasiswa kesehatan harus tahu!: Berpartisipasi dan berkolaborasi dalam sistem pendidikan tinggi ilmu kesehatan. 
Jakarta: Dikti - Kementerian

Pendidikan dan Kebudayaan; 2011.

14. Pfaff MA. Learning together: The image gently interprofessional simulation for nursing and allied health students. Teach Learn Nurs. 2014 Jul;9(3):108-14.

15. Sedyowinarso $M$, Fauziah $F$, Aryakhiyati N, Julica M, Sulistyowati E, Masriati F, et al. Persepsi dan Kesiapan Mahasiswa \& Dosen Profesi Kesehatan terhadap Model Pembelajaran Pendidikan Interprofesi: Kajian Nasional Mahasiswa Ilmu Kesehatan. Dikti Kementerian Pendidikan dan Kebudayaan; 2011.

16. Freeth D, Barr H, Barr H. Effective Interprofessional Education: Development, Delivery, and Evaluation. United Kingdom: Oxford: Blackwell Publishing; 2005.

17. Interprofessional Educational Collaborative, Practice IC, Values U. Core Competencies for Interprofessional Collaborative Practice: 2016 Update. 2016 p. 10-1.

18. Page RL, Hume AL, Trujillo JM, Leader WG, Vardeny O, Neuhauser $\mathrm{MM}$, et al. Interprofessional Education: Principles and Application A Framework for Clinical Pharmacy. Pharmacotherapy. 2009 Jul;29 (7):879-879.

19. Gilbert J. Interprofessional Education for Collaborative, PatientCentred Practice. Nurs Leadersh. 2005 May 15;18(2):32-8. 